\title{
Evaluation of bleeding disorders in patients with Noonan syndrome: a systematic review
}

Diane J Nugent ${ }^{\prime}$

Alicia A Romano ${ }^{2}$

Shreya Sabharwal ${ }^{3}$

David L Cooper ${ }^{3}$

'Center for Inherited Bleeding Disorders, Children's Hospital of Orange County, Orange, CA, USA; ${ }^{2}$ Department of Pediatrics, New York Medical College, Valhalla, NY, USA; ${ }^{3}$ Medical and Regulatory Affairs, Novo Nordisk Inc, Plainsboro, NJ, USA
Correspondence: Diane J Nugent Center for Inherited Bleeding Disorders, Children's Hospital of Orange County, 1010 West La Veta Avenue, Suite 670, Orange, CA 92868, USA

$\mathrm{Tel}+17142211200$

Fax + I 714 22I 1299

Email dianenugent7@gmail.com
This article was published in the following Dove Press journal: Journal of Blood Medicine

Background: Noonan syndrome (NS) is an autosomal dominant genetic condition that has a number of clinical features, including bleeding diathesis and a number of hematological abnormalities including clotting factor deficiencies, von Willebrand disease and abnormal platelet count/function. Methods: We evaluated the frequency/types of bleeding disorders, and associated hematological laboratory findings, in patients with NS, using published data from 1965 to 2014.

Results: Of 45 studies identified, 31 included data for 428 patients with NS. Of these patients, $43 \%$ had reported bleeding, $26 \%$ had no reported bleeding and no bleed data was reported for $31 \%$. Most patients (90\%) had bleeding-related laboratory test abnormalities, but only 194 (45\%) had a confirmed diagnosis of a specific bleeding disorder. Abnormal laboratory tests included: prolonged prothrombin time, activated partial thromboplastin time, and other platelet-related disorders. Of the 194 patients with a confirmed diagnosis of a specific bleeding disorder, 153 (79\%) had single clotting factor deficiencies, von Willebrand disease or platelet-related disorders, and $41(21 \%)$ had multiple deficiencies including platelet-related disorders.

Conclusion: As patients with NS can experience multiple bleeding disorders, including abnormal platelet function, clinical evaluations should be performed at diagnosis, after diagnosis, before any surgery is undertaken, and if patients become symptomatic.

Keywords: bleeding disorders, children, laboratory test abnormalities, Noonan syndrome, screening, surgical procedures

\section{Introduction}

Noonan syndrome (NS) is an autosomal dominant genetic condition that affects one in 1,000-2,500 individuals. Typical signs of NS include characteristic facial features, short stature, congenital heart defect, skeletal and thoracic anomalies, developmental delay, and bleeding problems; these are seen in $30 \%-72 \%$ of patients with the condition. ${ }^{1}$ Until recently, the molecular etiology of NS was unknown; this, coupled with the highly variable phenotype observed in these patients, made diagnosis difficult. It is now recognized, however, that $\sim 50 \%$ of patients with NS demonstrate pathological variants of the PTPN11 gene. This results in the development of NS, or another disorder involving PTPN11 (such as LEOPARD syndrome), where cardiac defects also frequently manifest as pulmonary valve stenosis and hypertrophic cardiomyopathy. ${ }^{2}$ A number of genes are known to play a role in NS; molecular testing of the four bestrecognized genes in NS is now generally available and has identified mutations in PTPN11 in $~ 50 \%, K R A S$ in $<5 \%$, SOS1 in $~ 15 \%$, and $R A F 1$ in $3 \%-17 \%$ of patients with the disorder. ${ }^{3}$ 
NS can be associated with an increased risk of bleeding and bruising, and a variety of bleeding abnormalities, with factor XI deficiency and platelet abnormalities being described most frequently. ${ }^{46}$ However, it is not clear whether there is any direct correlation between bleeding risk and results of coagulation tests so there is currently increased focus on evaluating bleeding risk in patients with NS. As a consequence of their condition, many patients undergo multiple surgeries, often starting in early childhood, so it is important to establish bleeding risk prior to any intervention. For example, pulmonary valve stenosis, which is often reported in patients with NS, is typically unsuitable for interventional balloon dilation due to bleeding risk, and usually requires surgery for correction. Also, the presence of a partial atrioventricular canal with outflow obstruction can result in a demanding surgical procedure to correct the malformation. ${ }^{7}$ The aim of this systematic review was to identify the frequency and types of bleeding disorders, and to evaluate any links with associated laboratory findings, in patients with NS, with a view to providing physicians with guidelines on how to evaluate bleeding complications in patients with NS.

\section{Methods and results}

Publications from 1965 to 2014 were reviewed. They included trials, case reports/series, and reviews identified via MEDLINE $^{\circledR}$, EMBASE $^{\circledR}$, and Scopus ${ }^{\circledR}$. Key search terms included: Noonan; bleed*3; hemorrhag*3; thrombocytop*enia; $\mathrm{h}$ *emostatic; $\mathrm{h} *$ emostasis; bleed* diathesis; platelet* disorder*.
Studies of patients with NS were included in the analysis only if the bleeding phenotype was described. Studies were excluded if NS was not present or not confirmed in all cases; the publication was a secondary analysis (review of other case reports with no new information); there was no patient-level bleeding phenotype information reported for any patients. All available patient data were abstracted, and included demographics, bleeding symptoms, laboratory abnormalities, bleeding score, and specific disorders reported. The numbers of patients in each study are shown in Table $\mathrm{S} 1$.

Of 45 studies identified, ${ }^{1,4-6,8-48} 31^{4-6,8-35}$ had relevant data from 428 patients with NS (Figure 1). Of the 31 studies included, 13 were single case studies, five included $<10$ patients, and 13 included $>10$ patients. The largest cumulative study, including 151 patients, ${ }^{18}$ had previously been reported with $72^{5}$ and $31^{33}$ patients; however, different sets of information are presented in each publication. Nearly half $(49 \%)$ of the patients were male; $43 \%$ (183 patients) had reported bleeding, 26\% (112 patients) had not reported bleeding, and for 31\% (133 patients) there was no data on bleeding. Most patients (384; 90\%) had some reported laboratory test abnormalities (platelet function and/or coagulation abnormalities). Of the patients with reported bleeding, abnormal laboratory tests included: prolonged prothrombin time (PT) (29 patients; 7\%); activated partial thromboplastin time (aPTT) (71 patients; 17\%); PT/aPTT (23 patients; 5\%); and platelet-related disorders (42 patients; $10 \%$ ). There were also reports of normal PT (104 patients; 24\%) and aPTT (157 patients; $37 \%)$.
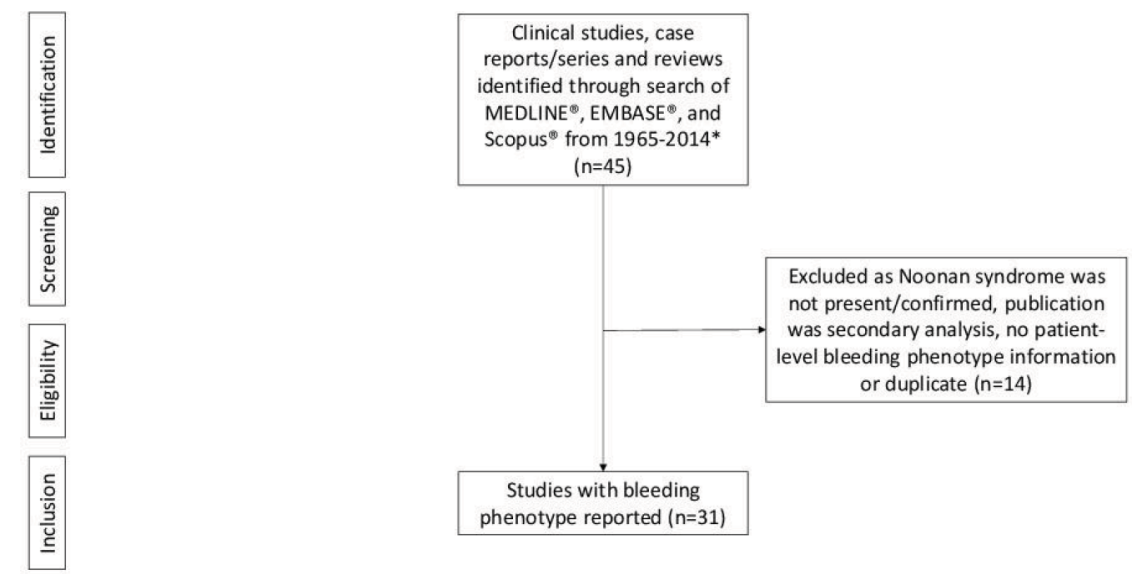

Figure I Prisma figure of studies for inclusion.

Note: *Key search terms included: Noonan; bleed*3; hemorrhag*3; thrombocytop*enia; $h^{*}$ emostatic; $h^{*}$ emostasis; bleed* diathesis; platelet* disorder*. 
In one of the studies of 39 patients (and 28 controls), nearly $40 \%$ of patients with NS had a bleeding diathesis but $>90 \%$ had platelet function and/or coagulation abnormalities. ${ }^{9}$ Another study of 13 patients suggested that bleeding signs do not appear to be due to coagulation disorders. ${ }^{22}$

Of the 428 patients evaluated, only $46 \%$ (195 patients) had a specific diagnosis of factor deficiency, von Willebrand disease, or platelet-related disorder. Of these patients, 154 (78\%) had single-factor deficiencies or von Willebrand disease, and 42
(22\%) had multiple factor deficiencies (Table 1). Of the factor deficiencies, factor XI (FXI) deficiency was most common (81 patients), followed by factor XII (FXII) (34 patients), and factor VIII (FVIII) (28 patients) (Table 2). Platelet-related disorders were reported in 46 patients, with thrombocytopenia and platelet aggregation abnormality being most commonly reported. In the 42 patients reporting multiple factor deficiencies, FXI+ FXII combined (11 patients), and FVIII+ FXI combined (seven patients) were the most common (Table 2).

Table I Factor deficiencies and other bleeding disorders reported in patients with NS

\begin{tabular}{llll}
\hline Type of deficiency & Single factor deficiency & Multiple factor deficiency & Total \\
\hline FI & 2 & 1 & 3 \\
FII & 0 & 1 & 1 \\
FV & 0 & 5 & 5 \\
FVII & 6 & 6 & 12 \\
FVIII & 18 & 12 & 30 \\
FIX & 4 & 7 & 1 I \\
FX & 0 & 5 & 5 \\
FXI & 57 & 30 & 87 \\
FXII & 19 & 16 & 35 \\
FXIII & 1 & 0 & 1 \\
vWD & 4 & 6 & 10 \\
Platelet-related & 42 & 5 & 47 \\
Total $^{b}$ & 153 & 42 & 195 \\
\hline
\end{tabular}

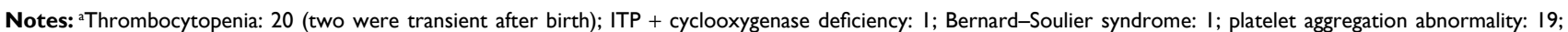
platelet storage pool deficiency: I. 'botal is the number of patients with factor deficiencies, and for multiple factor deficiencies patients could have more than one deficiency type.

Abbreviations: ITP, idiopathic thrombocytopenia; FI, factor I; FII, factor II; FV, factor V; FVII, factor VII; FVIII, factor VIII; FIX, factor IX; FX, factor X; FXI, factor XI, FXII, factor XII; FXIII, factor XIII; NS, Noonan syndrome; vWD, von Willebrand disease.

Table 2 Multiple factor deficiencies and platelet-related disorders reported in patients with NS

\begin{tabular}{|c|c|}
\hline Multiple factor deficiency & Number of patients \\
\hline $\mathrm{FI}+\mathrm{FXI}+\mathrm{FXII}$ & 1 \\
\hline $\mathrm{FII}+\mathrm{FXI}$ & 1 \\
\hline $\mathrm{FV}+\mathrm{FVII}+\mathrm{FX}$ & 1 \\
\hline $\mathrm{FV}+\mathrm{FVIII}$ & 3 \\
\hline$F V+F I X+F X$ & 1 \\
\hline$F V I I+F I X+F X I+v W D$ & 2 \\
\hline $\mathrm{FVII}+\mathrm{FX}$ & 2 \\
\hline FVII + FXII + platelet-related disorder & 1 \\
\hline$F V I I I+F X I+F X I I$ & 1 \\
\hline FVIII + vWD & 1 \\
\hline $\mathrm{FVIII}+\mathrm{FXI}$ & 7 \\
\hline $\mathrm{FIX}+\mathrm{FX}$ & 1 \\
\hline FIX + FXII + platelet-related disorder & 1 \\
\hline $\mathrm{FIX}+\mathrm{FXI}$ & 2 \\
\hline$F X I+F X I I$ & 11 \\
\hline$F X I+v W D$ & 2 \\
\hline FXI + platelet-related disorder & 3 \\
\hline FXII + vWD & 1 \\
\hline Total & 42 \\
\hline
\end{tabular}

Notes: aPlatelet-related disorders included: thrombocytopenia; idiopathic thrombocytopenic purpura + cyclooxygenase deficiency; Bernard-Soulier syndrome, platelet aggregation abnormality; platelet storage pool deficiency.

Abbreviations: FI, factor I; FII, factor II; FV, factor V; FVII, factor VII; FVIII, factor VIII; FIX, factor IX; FX, factor X; FXI, factor XI, FXII, factor XII; FXIII, factor XIII; NS, Noonan syndrome; vWD, von Willebrand disease. 


\section{Discussion}

Physicians are diagnosing NS more readily; however, this literature review identifies a clear gap in the evaluation and diagnosis of bleeding diathesis and specific bleeding disorders in these patients. Indeed, several studies have highlighted that there is no correlation between coagulation study results and bleeding risk. In one study of 39 patients (and 28 controls), whilst only $40 \%$ of patients with NS had a bleeding diathesis, more than $90 \%$ had platelet function and/or coagulation abnormalities. ${ }^{9}$ Another study of 13 patients suggested that bleeding signs do not appear to be due to coagulation disorders. ${ }^{22}$ These findings suggest that screening needs to include tests beyond PT, aPTT and platelet count. Therefore, guidelines for clinical evaluation in NS should highlight the importance of comprehensive testing, as well as the need for specialist involvement by a pediatric hematologist in differential diagnosis, both at diagnosis of NS and pre-operatively, whenever screening test abnormalities are identified. ${ }^{49}$

Although there is currently no consensus on the optimum strategy for diagnosis of bleeding in patients with NS, a review by Roberts et al in 2013 suggested that at diagnosis of NS a complete blood cell count (CBC) with differential and PT/aPTT should be undertaken. After diagnosis, repeat $\mathrm{CBC}$ with differential and PT/aPTT if aged 6-12 months at initial screen, and pre-operatively, $\mathrm{CBC}$ with differential and PT/aPTT, then in consultation with hematologist FIX, FXI and FXII concentrations, von Willebrand factor, and platelet aggregation. Furthermore, if symptomatic, PT/aPTT if bleeding is abnormal or persistent, then refer to a hematologist. ${ }^{50}$

Due to the inconsistent reporting of platelet test results and platelet disorders in the studies included in this analysis, it does not appear that appropriate tests are being undertaken in clinical practice. Platelet aggregation, for example, needs to be conducted on a fresh specimen and is more likely to be offered at regional centers. It is therefore important to distinguish between abnormalities in platelet function suspected by screening tests (eg, platelet function analysis-100) and confirmed platelet function disorders based upon aggregometry patterns and confirmed with flow cytometry, electron microscopy, or genetic testing.

The surprisingly high incidence of multiple coagulation disorders suggests that work up in patients with NS needs to be more comprehensive. While FXI deficiency was most common individually and in combination, there were several multiple defects (both factor deficiencies and platelet function disorders) reported in the same patient.

Given that several germline mutations including PTPN11 and $S O S 1$ are reported in patients with NS, there may be a possible correlation with bleeding phenotype. However, of the studies included in our analysis, only a few evaluated genetic mutations in relation to the reported bleeding disorder and results were not consistent. An evaluation of patients with NS reported PTPN11 gene mutations in 21 of 27 patients, and hematological disorders in nine of 27 , with authors suggesting a near significant correlation. ${ }^{12}$ Another study of 19 patients with NS showed that coagulation abnormalities were reported in patients with PTPN11, SOS1 and SOS1/RAF1 mutations and without a gene mutation, but they were not correlated with a specific gene mutation. ${ }^{14}$ In addition, a study of 13 patients with NS (six with PTPN11 mutations) found that 12/13 had normal hematological assessment and only one had a platelet function disorder (storage pool disease). ${ }^{22}$ One of the studies of 15 patients (14 with PTPN11 mutation and one with SOS1 mutation), showed that nine had a bleeding diathesis and complained of easy bruising, despite having normal platelet count, basic coagulation parameters, fibrinogen and antithrombin, and without a relevant reduction of coagulation factor activities. Furthermore, three of them had potentially acquired von Willebrand disease, which the authors suggested may explain the bleeding in those with pulmonary stenosis. ${ }^{47}$ Further analysis of a large cohort of individuals with NS has suggested that PTPN11 gene mutations are more likely to be found in those with pulmonary stenosis, whereas hypertrophic cardiomyopathy is less prevalent among those with PTPN11 mutations. ${ }^{2}$ Thus, bleeding disorders in NS do not appear to correlate with a particular genotype.

There are limitations to this analysis, which included mostly spontaneous case reports/series, because the reporting of symptoms, laboratory evaluations, and diagnosis may have been incomplete. Furthermore, while attempts were made to remove duplicate reporting of the same case in both an individual case report and prior compiled series/review, there may have been cases that were not explicitly referenced. When limited coagulation evaluation does not confirm to one or more specific diagnoses, it underscores the importance of referral to a pediatric hematologist so that the patient's parents can give a detailed bleeding history. This should then be followed through with a differential diagnosis, using appropriate laboratory assays. In future case reports/series, there is an important need to ensure that symptoms, laboratory results, and ultimate diagnoses are tracked.

\section{Conclusion}

Patients with NS can experience multiple bleeding disorders, including platelet-related disorders. Comprehensive clinical evaluations should be carried out both at diagnosis, after 
diagnosis if patients are symptomatic, and prior to any surgical procedures, even if tests are normal, the risk for bleeding events should be carefully considered. Furthermore, as there is no current consensus on management of bleeding complications in patients with NS, it is important that physicians closely monitor these patients.

\section{Acknowledgments}

Some study information presented in this manuscript was previously presented as a poster at The American Society of Pediatric Hematology/Oncology (ASPHO) 2016 congress. Poster\#549: "Evaluation of bleeding disorders in patients with Noonan syndrome: a systematic review". Nugent D, Romano A, Sabharwal S, Germak J, Cooper DL. Editorial assistance for this manuscript was provided by PAREXEL, and funded by Novo Nordisk A/S.

\section{Disclosure}

Alicia A Romano is a consultant for Novo Nordisk and Genentech, and is on the speaker bureau for Novo Nordisk, Genentech, and Genzyme Corporation. Shreya Sabharwal and David L Cooper are employees of Novo Nordisk. The authors report no other conflicts of interest in this work.

\section{References}

1. Briggs BJ, Dickerman JD. Bleeding disorders in Noonan syndrome. Pediatr Blood Cancer. 2012;58(2):167-172.

2. Tartaglia M, Kalidas K, Shaw A, et al. PTPN11 mutations in Noonan syndrome: molecular spectrum, genotype-phenotype correlation, and phenotypic heterogeneity. Am J Hum Genet. 2002;70(6):1555-1563.

3. Turner AM. Noonan syndrome. J Paediatr Child Health. 2014;50(10):E14-E20.

4. Massarano AA, Wood A, Tait RC, Stevens R, Super M. Noonan syndrome: coagulation and clinical aspects. Acta Paediatr. 1996;85(10): 1181-1185.

5. Sharland M, Patton MA, Talbot S, Chitolie A, Bevan DH. Coagulationfactor deficiencies and abnormal bleeding in Noonan's syndrome. Lancet. 1992;339(8784):19-21.

6. Kitchens CS, Alexander JA. Partial deficiency of coagulation factor $\mathrm{XI}$ as a newly recognized feature of Noonan syndrome. $J$ Pediatr. 1983;102(2):224-227.

7. Formigari R, Michielon G, Digilio MC, et al. Genetic syndromes and congenital heart defects: how is surgical management affected? Eur $J$ Cardiothorac Surg. 2009;35(4):606-614.

8. Argyrou A, Marinakis T, Kalofolias N, Papazoglou S. Thrombotic thrombocytopenic purpura in a young patient with Noonan syndrome and systemic lupus erythematosus. Arch Hell Med. 2010;27(3): 545-548.

9. Artoni A, Selicorni A, Passamonti SM, et al. Hemostatic abnormalities in Noonan syndrome. Pediatrics. 2014;133(5):e1299-e1304.

10. Bertola DR, Carneiro JD, D'Amico EA, et al. Hematological findings in Noonan syndrome. Rev Hosp Clin Fac Med Sao Paulo. 2003;58(1):5-8.

11. de Haan M, Vd Kamp JJ, Briët E, Dubbeldam J. Noonan syndrome: partial factor XI deficiency. Am J Med Genet. 1988;29(2):277-282.

12. González-Casado I, Barreda Bonis A, Salamanca Fresno L, et al. Noonan syndrome and hemato-oncological anomalies. Horm Res Paediatr. 2011;76(Suppl 2):167-168.
13. Flick JT, Singh AK, Kizer J, Lazarchick J. Platelet dysfunction in Noonan's syndrome. A case with a platelet cyclooxygenase-like deficiency and chronic idiopathic thrombocytopenic purpura. Am J Clin Pathol. 1991;95(5):739-742.

14. Gamba G, Marabotto F, Losa L, et al. Co-agulation factor deficiencies and abnormal bleeding in Noonan's syndrome. Horm Res Paediatr. 2011;76(Suppl 2):321.

15. Koç A, Kösecik M, Tatlı MM, Atas A, Emiroğlu HH. Bernard-Soulier syndrome like platelet defect in a patient with Noonan Syndrome; a case report. Turk J Haematol. 2001;18(3):191-193.

16. Nunes P, Aguilar S, Prado SN, Palaré MJ, Ferrão A, Morais A. Severe congenital thrombocytopaenia-first clinical manifestation of Noonan syndrome. BMJ Case Rep. 2012;2012:bcr1020114940.

17. Patrick K, Makris M. Images in haematology. Noonan syndrome associated with bleeding disorders. Br J Haematol. 2010;151(2):117.

18. Sharland M, Burch M, McKenna WM, Paton MA. A clinical study of Noonan syndrome. Arch Dis Child. 1992;67(2):178-183.

19. Staudt JM, van der Horst CM, Peters M, Melis P. Bleeding diathesis in Noonan syndrome. Scand J Plast Reconstr Surg Hand Surg. 2005;39(4):247-248.

20. Stoffman JM, Chodirker BN, Israels SJ. Coagulation abnormalities in patients with Noonan Syndrome - a single centre case series. Blood. 2004;104(11):1035-1035.

21. Tanaka $Y$, Masuno M, Iwamoto $H$, et al. Noonan syndrome and cavernous hemangioma of the brain. Am J Med Genet. 1999;82(3):212-214.

22. Troiano M, Gottlieb S, Rey R, et al. Noonan Syndrome: assessment of bleeding disorders. Horm Res Paediatr. 2011;76(Suppl 2):21.

23. Vortia E, Mahajan L, Kaplan B. Duodenal hematoma complicating upper endoscopy with biopsy in two pediatric patients with Noonan's syndrome: what pediatric gastroenterologists need to know. Am J Gastroenterol. 2011;106(Suppl 2):S400.

24. Waespe N, Prader S, Kroiss S, Knirsch W, Speer O, Schmuge M. Clinical and laboratory manifestations of bleeding diathesis in Noonan syndrome. Hämostaseologie. 2013;33(1):A74.

25. Witt DR, McGillivray BC, Allanson JE, et al. Bleeding diathesis in Noonan syndrome: a common association. Am JMed Genet. 1988;31(2):305-317.

26. Caralis DG, Char F, Graber JD, Voigt GC. Delineation of multiple cardiac anomalies associated with the Noonan syndrome in an adult and review of the literature. Johns Hopkins Med J. 1974;134(6):346-355.

27. Evans DG, Lonsdale RN, Patton MA. Cutaneous lymphangioma and amegakaryocytic thrombocytopenia in Noonan syndrome. Clin Genet. 1991;39(3):228-232.

28. Grange CS, Heid R, Lucas SB, Ross PL, Douglas MJ. Anaesthesia in a parturient with Noonan's syndrome. Can JAnaesth. 1998;45(4):332-336.

29. Humbert JA, Hammond KB, Hathaway WE. Trimethylaminuria: the fish-odour syndrome. Lancet. 1970;2(7676):770-771.

30. Komp DM. "Car. factor" deficiency revisited. Pediatric Res. 1975;9(4):184-189.

31. Phillips WG, Dunnill MG, Kurwa AR, Black MM. Orbital oedema: an unusual presentation of Noonan's syndrome. $\mathrm{Br} J$ Dermatol. 1993;129(2):190-192.

32. Sgouros SN, Karamanolis G, Papadopoulou E, et al. Postbiopsy intramural hematoma of the duodenum in an adult with Noonan's syndrome. J Gastroenterol Hepatol. 2004;19(10):1217-1219.

33. Sharland M, Patton MA, Chitolie A, Talbot S, Bevan D. Coagulation factor abnormalities in Noonan syndrome. J Med Genet. 1990;27(10):646.

34. Singer ST, Hurst D, Addiego JE. Bleeding disorders in Noonan syndrome: three case reports and review of the literature. J Pediatr Hematol Oncol. 1997;19(2):130-134.

35. Sugar AW, Ezsias A, Bloom AL, Morcos WE. Orthognathic surgery in a patient with Noonan's syndrome. J Oral Maxillofac Surg. 1994;52(4):421-425.

36. Char F, Rodriguez-Fernandez H, Scott C, Borgaonkar D, Bell D, Rowe D. The Noonan Syndrome - a clinical study forty-five cases. Birth Defects: Original Article Series. 1972;VIII(5):110-118.

37. Collins E, Turner G. The Noonan syndrome - a review of the clinical and genetic features of 27 cases. J Pediatr. 1973;83(6):941-950. 
38. Derbent M, Öncel Y, Tokel K, et al. Clinical and hematologic findings in Noonan syndrome patients with PTPN11 gene mutations. Am J Med Genet A. 2010;152A(11):2768-2774.

39. Hathaway WE. Bleeding disorders due to platelet dysfunction. Am J Dis Child. 19601971;121(2):127-134.

40. Hilgartner M, Engle AM, Redo SF. Cardiac surgery in patients with plasma thromboplastin antecedent (P.T.A.) deficiency. J Thorac Cardiovasc Surg. 1965;49:974-981.

41. Calvert GD. Trimethylaminuria and inherited Noonan's syndrome. Lancet. 1973;1(7798):320-321.

42. Noonan JA. Hypertelorism with Turner phenotype. A new syndrome with associated congenital heart disease. Am J Dis Child. 19601968;116(4):373-380.

43. Sharathkumar AA. Bleeding disorders and Noonan syndrome. Pediatric Blood Cancer. 2012;59(3):592; author reply 593. Available from: https://onlinelibrary.wiley.com/doi/pdf/10.1002/pbc.24151. Accessed September 18, 2018.

44. Smpokou P, Tworog-Dube E, Kucherlapati RS, Roberts AE. Medical complications, clinical findings, and educational outcomes in adults with Noonan syndrome. Am J Med Genet A. 2012;158A(12):3106-3111.
45. Tofil NM, Winkler MK, Watts RG, Noonan J. The use of recombinant factor VIIa in a patient with Noonan syndrome and life-threatening bleeding. Pediatr Crit Care Med. 2005;6(3):352-354.

46. Yoshida R, Hasegawa T, Hasegawa Y, et al. Protein-tyrosine phosphatase, nonreceptor type 11 mutation analysis and clinical assessment in 45 patients with Noonan syndrome. J Clin Endocrinol Metab. 2004;89(7):3359-3364.

47. Wiegand G, Hofbeck M, Zenker M, Budde U, Rauch R. Bleeding diathesis in Noonan syndrome: is acquired von Willebrand syndrome the clue? Thromb Res. 2012;130(5):e251-e254.

48. Biss TT, Blanchette VS, Clark DS, et al. Evaluation of bleeding symptoms in children with an inherited mucocutaneous bleeding disorder. Blood. 2009;114(22):1292-1292.

49. Romano AA, Allanson JE, Dahlgren J, et al. Noonan syndrome: clinical features, diagnosis, and management guidelines. Pediatrics. 2010;126(4):746-759.

50. Roberts AE, Allanson JE, Tartaglia M, Gelb BD. Noonan syndrome. Lancet. 2013;381(9863):333-342. 


\section{Supplementary materials}

Table SI Case reports/series on bleeding disorders in patients with NS

\begin{tabular}{|c|c|}
\hline Reference & Number of patients \\
\hline Argyrou A, et al. Arch Hell Med, 2010' & 1 \\
\hline Artoni A, et al. Pediatrics, $2014^{2}$ & 39 \\
\hline Bertola DR, et al. Rev Hosp Clin Fac Med Sao Paulo, $2003^{3}$ & 30 \\
\hline González Casado I, et al. Horm Res Paediatr. 201 I ${ }^{4}$ & 27 \\
\hline de Haan M, et al. Am J Med Genet. $1988^{5}$ & 12 \\
\hline Flick JT, et al. Am J Clin Pathol. 199/6 & I \\
\hline Gamba G, et al. Horm Res Paediatr. 201 I ${ }^{7}$ & 19 \\
\hline Kitchens CS, et al. J Pediatr. $1983^{8}$ & 4 \\
\hline Koc A, et al. Turk J Haematol. $200 I^{9}$ & I \\
\hline Massarano AA, et al. Acta Paediatr. $1996^{10}$ & 18 \\
\hline Nunes P, et al. BMJ Case Rep. 2012"1 & I \\
\hline Patrick K, et al. Br J Haematol. $2010^{12}$ & 1 \\
\hline Sharland M, et al. Arch Dis Child. $1992^{13}$ & $\left.15\right|^{\mathrm{a}}$ \\
\hline Sharland M, et al. Lancet. $1992^{14}$ & $72^{\mathrm{a}}$ \\
\hline Staudt JM, et al. Scand J Plast Reconstr Surg Hand Surg. $2005^{15}$ & I \\
\hline Stoffman JM, et al. Blood. 2004'16 & 28 \\
\hline Tanaka Y, et al. Am J Med Genet. $1999^{17}$ & 2 \\
\hline Troiano M, et al. Horm Res Paediatr. $201^{18}$ & 13 \\
\hline Vortia E, et al. Am J Gastroenterol. 20I I 19 & 2 \\
\hline Waespe N, et al. Hämostaseologie. $2013^{20}$ & 15 \\
\hline Witt DR, et al. Am J Med Genet. 1988² & 19 \\
\hline Caralis DG, et al. Johns Hopkins Med J. $1974^{22}$ & I \\
\hline Evans DG, et al. Clin Genet. $\left.199\right|^{23}$ & I \\
\hline Grange CS, et al. Can J Anaesth. $1998^{24}$ & I \\
\hline Humbert JA, et al. Lancet. $1970^{25}$ & I \\
\hline Komp DM, et al. Pediatr Res. $1975^{26}$ & 2 \\
\hline Phillips WG, et al. Br J Dermatol. $1993^{27}$ & I \\
\hline Sgouros SN, et al. J Gastroenterol Hepatol. 2004 28 & I \\
\hline Sharland M, et al. J Med Genet. $1990^{29}$ & $31^{\mathrm{a}}$ \\
\hline Singer ST, et al. J Pediatr Hematol Oncol. $1997^{30}$ & 3 \\
\hline Sugar AW, et al. J Oral Maxillofac Surg. 199431 & I \\
\hline
\end{tabular}

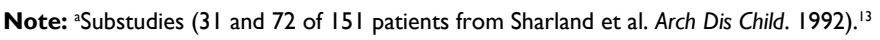

Abbreviation: NS, Noonan syndrome.

\section{References}

1. Argyrou A, Marinakis T, Kalofolias N, Papazoglou S. Thrombotic thrombocytopenic purpura in a young patient with Noonan syndrome and systemic lupus erythematosus. Arch Hell Med. 2010;27(3):545-548.

2. Artoni A, Selicorni A, Passamonti SM, et al. Hemostatic abnormalities in Noonan syndrome. Pediatrics. 2014;133(5):e1299-e1304.

3. Bertola DR, Carneiro JD, D'Amico EA, et al. Hematological findings in Noonan syndrome. Rev Hosp Clin Fac Med Sao Paulo. 2003;58(1):5-8.

4. González-Casado I, Barreda Bonis A, Salamanca Fresno L, et al. Noonan syndrome and hemato-oncological anomalies. Horm Res Paediatr. 2011;76(Suppl 2):167-168.

5. de Haan M, Vd Kamp JJ, Briët E, Dubbeldam J. Noonan syndrome: partial factor XI deficiency. Am J Med Genet. 1988;29(2):277-282.

6. Flick JT, Singh AK, Kizer J, Lazarchick J. Platelet dysfunction in Noonan's syndrome. A case with a platelet cyclooxygenase-like deficiency and chronic idiopathic thrombocytopenic purpura. Am J Clin Pathol. 1991;95(5):739-742.

7. Gamba G, Marabotto F, Losa L, et al. Co-agulation factor deficiencies and abnormal bleeding in Noonan's syndrome. Horm Res Paediatr. 2011;76(Suppl 2):321.
8. Kitchens CS, Alexander JA. Partial deficiency of coagulation factor $\mathrm{XI}$ as a newly recognized feature of Noonan syndrome. J Pediatr. 1983;102(2):224-227.

9. Koç A, Kösecik M, Tatlı MM, Atas A, Emiroğlu HH. Bernard-Soulier Syndrome like platelet defect in a patient with noonan syndrome; a case report. Turk J Haematol. 2001;18(3):191-193.

10. Massarano AA, Wood A, Tait RC, Stevens R, Super M. Noonan syndrome: coagulation and clinical aspects. Acta Paediatr. 1996;85(10):1181-1185.

11. Nunes P, Aguilar S, Prado SN, Palaré MJ, Ferrão A, Morais A. Severe congenital thrombocytopaenia - first clinical manifestation of Noonan syndrome. BMJ Case Rep. 2012;2012:bcr1020114940.

12. Patrick K, Makris M. Images in haematology. Noonan syndrome associated with bleeding disorders. Br J Haematol. 2010;151(2):117.

13. Sharland M, Burch M, McKenna WM, Paton MA. A clinical study of Noonan syndrome. Arch Dis Child. 1992;67(2):178-183.

14. Sharland M, Patton MA, Talbot S, Chitolie A, Bevan DH. Coagulationfactor deficiencies and abnormal bleeding in Noonan's syndrome. Lancet. 1992;339(8784):19-21.

15. Staudt JM, van der Horst CM, Peters M, Melis P. Bleeding diathesis in Noonan syndrome. Scand J Plast Reconstr Surg Hand Surg. 2005;39(4):247-248. 
16. Stoffman JM, Chodirker BN, Israels SJ. Coagulation abnormalities in patients with Noonan Syndrome - a single centre case series. Blood. 2004;104(11):1035-1035.

17. Tanaka Y, Masuno M, Iwamoto H, et al. Noonan syndrome and cavernous hemangioma of the brain. Am J Med Genet. 1999;82(3):212-214.

18. Troiano M, Gottlieb S, Rey R, et al. Noonan Syndrome: assessment of bleeding disorders. Horm Res Paediatr. 2011;76(Suppl 2):21.

19. Vortia E, Mahajan L, Kaplan B. Duodenal hematoma complicating upper endoscopy with biopsy in two pediatric patients with Noonan's syndrome: what pediatric gastroenterologists need to know. Am J Gastroenterol. 2011;106(Suppl 2):S400.

20. Waespe N, Prader S, Kroiss S, Knirsch W, Speer O, Schmuge M. Clinical and laboratory manifestations of bleeding diathesis in Noonan syndrome. Hämostaseologie. 2013;33(1):A74.

21. Witt DR, Mcgillivray BC, Allanson JE, et al. Bleeding diathesis in Noonan syndrome: a common association. Am JMed Genet. 1988;31(2):305-317.

22. Caralis DG, Char F, Graber JD, Voigt GC. Delineation of multiple cardiac anomalies associated with the Noonan syndrome in an adult and review of the literature. Johns Hopkins Med J. 1974;134(6):346-355.

23. Evans DG, Lonsdale RN, Patton MA. Cutaneous lymphangioma and amegakaryocytic thrombocytopenia in Noonan syndrome. Clin Genet. 1991;39(3):228-232.
24. Grange CS, Heid R, Lucas SB, Ross PL, Douglas MJ. Anaesthesia in a parturient with Noonan's syndrome. Can J Anaesth. 1998;45(4):332-336.

25. Humbert JA, Hammond KB, Hathaway WE. Trimethylaminuria: the fish-odour syndrome. Lancet. 1970;2(7676):770-771.

26. Komp DM. "Car. factor" deficiency revisited. Pediatric Res. 1975;9(4):184-189.

27. Phillips WG, Dunnill MG, Kurwa AR, Black MM. Orbital oedema: an unusual presentation of Noonan's syndrome. Br J Dermatol. 1993;129(2):190-192.

28. Sgouros SN, Karamanolis G, Papadopoulou E, et al. Postbiopsy intramural hematoma of the duodenum in an adult with Noonan's syndrome. J Gastroenterol Hepatol. 2004;19(10):1217-1219.

29. Sharland M, Patton MA, Chitolie A, Talbot S, Bevan D. Coagulation factor abnormalities in Noonan syndrome. $J$ Med Genet. 1990;27(10):646.

30. Singer ST, Hurst D, Addiego JE. Bleeding disorders in Noonan syndrome: three case reports and review of the literature. J Pediatr Hematol Oncol. 1997;19(2):130-134.

31. Sugar AW, Ezsias A, Bloom AL, Morcos WE. Orthognathic surgery in a patient with Noonan's syndrome. J Oral Maxillofac Surg. 1994;52(4):421-425.
Journal of Blood Medicine

\section{Publish your work in this journal}

The Journal of Blood Medicine is an international, peer-reviewed, open access, online journal publishing laboratory, experimental and clinical aspects of all aspect pertaining to blood based medicine including but not limited to: Transfusion Medicine; Blood collection, Donor issues, Transmittable diseases, and Blood banking logistics; Immunohematology; Artificial and alternative
Dovepress

blood based therapeutics; Hematology; Biotechnology/nanotechnology of blood related medicine; Legal aspects of blood medicine; Historical perspectives. The manuscript management system is completely online and includes a very quick and fair peer-review system. Visit http://www.dovepress.com/ testimonials.php to read real quotes from published authors. 